\title{
Review: \\ Bioaccumulation of heavy metals in fish and other aquatic organisms from Karachi Coast, Pakistan
}

\author{
RAMZY A. YOUSIF ${ }^{1, \bullet}$, MUHAMMAD IQBAL CHOUDHARY ${ }^{2}$, SHAKEL AHMED ${ }^{2}$, QURATULAN AHMED ${ }^{3}$ \\ ${ }^{1}$ Department of Fisheries and Wildlife Science, Sudan University of Science and Technology. P.O.BOX 204, Khartoum, Sudan. Tel./fax.: +249-912- \\ 802311, `email: ramzy@ sustech.edu; ramzy173@gmail.com \\ ${ }^{2}$ H.E.J. Research Institute of Chemistry, International Centre for Chemical and Biological Sciences, University of Karachi. Karachi 75270, Pakistan \\ ${ }^{3}$ The Marine Reference Collection and Resources Centre, University of Karachi. Karachi 75270, Pakistan
}

Manuscript received: 25 December 2020. Revision accepted: 10 February 2021.

\begin{abstract}
Yousif RA, Choudhary MI, Ahmed S, Ahmed Q. 2021. Review: Bioaccumulation of heavy metals in fish and other aquatic organisms from Karachi Coast, Pakistan. Nusantara Bioscience 13: 73-84. Heavy metals are being utilized in a variety of ways in industries, agriculture, food processing and household in many forms. Metals are unique environmental and industrial pollutants in the sense that they are neither created nor destroyed by human beings but are only transported and transformed into various products. The present study deals with the findings of various investigators on the effect of heavy metals on fish and other aquatic organisms on Karachi coasts of Pakistan. The polluted areas (Rivers and Karachi coasts) receiving effluents from industrial, agricultural, municipal and domestic wastes. The order of abundance of the metals were as fellow; $\mathrm{Fe}>\mathrm{Zn}>\mathrm{Cu}>\mathrm{Mn}>\mathrm{Cd}>\mathrm{Pb}>\mathrm{Cr}>\mathrm{Ni}>\mathrm{Hg}>\mathrm{As}$. $\mathrm{Most}$ studies showed that essential metals $(\mathrm{Fe}, \mathrm{Zn}, \mathrm{Cu}$, and $\mathrm{Mn}$ ) in aquatic organisms are much high, but the quantities of non-essential metals are found to be less. This review has shown that fish and other aquatic organisms are used as bio-monitoring species in heavy metal pollution. It is suggested that such investigations should be continuous in terms of both human health and determination of metal pollution in aquatic environment.
\end{abstract}

Keywords: Aquatic organisms, fish, heavy metals, Karachi Coast

\section{INTRODUCTION}

Heavy metals are essential components of aquatic environment, usually found in really low concentrations. The many parts of the heavy metals released into the earth discover their way into the freshwater and marine environment as by many ways as input of direct air deposition, climatic, and disintegration due to rainwater. The levels of heavy metals are too high, in the area where domestic activities, mining activities, mechanical and cultivating activities are across the natural areas (Langston 1990; Bryan and Langston 1992; Sulieman and Suliman 2019).

Heavy metals accumulated in the fish and other aquatic organisms in two ways direct and indirect accumulation, consumption of contaminated water and food through the digestive system considered as direct exposure or indirectly through the permeable membranes such as skin and gills. The level of heavy metals concentration in fish and other aquatic organisms' organs indicate their levels also in their surrounding environment. The accumulation of heavy metals in aquatic organism organs sometimes can exceed the environmental levels. The toxic effect usually occurs when the rate of uptake is exceeding the mechanism of metabolism, storage, and detoxification (Ali et al. 2011; Baki et al. 2018; Rajeshkumar and Li 2018).
Contamination of the freshwater and marine environment by heavy metals has been reported by many authors such as Rashed (2001), Rahman et al. (2012), Yousif et al. (2016) and Rajeshkumar and Li (2018), have reported that zinc, chromium, mercury, lead, copper, cadmium and arsenic are the important metals which contaminate the water and harmful to aquatic organisms. Many marine organisms (fish, shrimp, and crab) at the highest point of the natural feeding ground items and aggregates high levels of metals from the water and sediment (Lambert et al. 2000; Tüzen 2003; Arulkumar et al. 2017; Daellenbach et al. 2017; Narsimha and Wang 2018). Heavy metals accumulated in aquatic organisms and their effect can move to the human after using contaminated fish and other aquatic organisms and the consequences can deteriorate the human health (Raja et al. 2009; Alinnor and Obiji 2010; Abarshi et al. 2017).

The levels of dangerous contaminants in aquatic organisms are a critical factor in view of their potential effects on the organisms themselves and the health status of humans that utilize them. Health organizations and institutions, for example, Food and Drug Administration (FDA), have started late raised stresses over the security of fisheries obtained from business sources (Burger et al. 2004). 


\section{THE MAIN SOURCES OF HEAVY METALS}

Contaminations of heavy metals in water also lead to changes in the chemical components of the aquatic environment, usually influences the behavioral, physiological, and bloodstream patterns, cell structures ionic balance (Oikari and Soivio 1976), liver function, and carbohydrate metabolism (Oikari and Soivio 1976; Oikari and Nakari 1982) of fishes. Earlier studies, showed that anthropogenic activities and domestic effluent constitute huge sources of heavy metal which contribute to the steadily increasing metallic pollutant in aquatic environment in most part of the world (Jibiri and Adewuyi 2008; Ates et al. 2015).

Recent development and advancements in the agricultural sector, industrialization, and urbanization have contributed substantially to elevated heavy metal pollution in freshwater and marine environments. Anthropogenic activities such as mining and smelting (Chen et al. 2015), combustion of fossil fuel refining (Muradoglu et al. 2015), discharge and disposal of domestic and municipal wastes (Khan et al. 2016), using pesticides in agricultural sector (Ogunlade and Agbeniyi 2011), sewage irrigation in some countries (Sun et al. 2013), fertilizer and urea application (Atafar et al. 2010), dust (Chen et al. 2011) contribute to spread the levels and concentrations of dangerous heavy metals in the aquatic environments. The major sources of heavy metals are summarized in Table 1.

Generally, metals can be categorized as biologically essential and nonessential. The nonessential metals (e.g., lead $(\mathrm{Pb})$, mercury $(\mathrm{Hg})$, cadmium $(\mathrm{Cd})$, aluminum $(\mathrm{Al})$, and tin $(\mathrm{Sn})$ ) no study has proven their biological function (also called xenobiotics elements or foreign elements), and their effects and toxicity rise with increasing the levels and concentration of these metals, on the other hand essential metals (e.g., zinc $(\mathrm{Zn})$, iron $(\mathrm{Fe})$ copper $(\mathrm{Cu})$, cobalt $(\mathrm{Co})$, nickel (Ni), chromium (Cr) and molybdenum (Mo)), have a known their biological role, and their effects and toxicity occur either at metabolic deficiencies or at high levels and concentrations of these metals (Sfakianakis et al. 2015). The deficiency of an essential metal can lead to adverse health effects, whereas the high levels of essential elements can also lead to negative effects which are equivalent to or worse than those effects caused by non-essential metals (Kennedy 2011; Sfakianakis et al. 2015). The most commonly investigated and found heavy metals in fish and other aquatic organisms in many studies are $\mathrm{Zn}, \mathrm{Cu}, \mathrm{Pb}, \mathrm{Cr}$, $\mathrm{Cd}, \mathrm{Ni}, \mathrm{Hg}, \mathrm{Co}, \mathrm{Sn}$, and Mo. Amongst them, the most frequently studied, with respect to fish and aquatic organisms' deformities, include $\mathrm{Zn}, \mathrm{Pb}, \mathrm{Cu}, \mathrm{Cr}, \mathrm{Cd}$, and $\mathrm{Hg}$.

\section{ACCUMULATION OF HEAVY METALS AND THE ECOLOGICAL STATUS OF AQUATIC ORGANISMS}

The rapid development of industry and agriculture has resulted in an increase in the pollution of coastal areas with heavy metals, which have been identified as a significant environmental hazard for invertebrates, fish, and humans
(Yousif et al. 2016; Khan and Strand 2018) Significant quantities of heavy metals in waster water are discharged into aquatic environments. These metals can be strongly accumulated and biomagnified along water, sediment, and aquatic food chains, thus resulting in sublethal effects or death in local fish populations and other aquatic animals (Yi and Zhangc 2012). Heavy metals like copper and zinc are essential for fish metabolism, while others such as mercury, cadmium, and lead have no known role in biological systems (Yi and Zhangc 2012; Ates et al. 2015). Therefore, it is important to better understand the relationships between ecological status of aquatic organisms and the concentrations of both essential and nonessential metals. Heavy metal pollution of water and sediment in the Karachi Coast has attracted much attention from researchers (Ahmed et al. 2017b).

\section{HEAVY METAL AND HUMAN HEALTH}

Consumption of contaminated food is the main source of exposure of humans to the risks of heavy metals (Liu et al. 2010). The presence of heavy metal in commercial fish can pose potential health risks to humans (Cid et al. 2001; Castro-gonzález and Méndez-armenta 2008; Saeedi et al. 2012; Ullah et al. 2017). Hence, it is important to know the level and concentration of heavy metal contents in aquatic organisms in order to ensure that it does not expose any hazard to the human and maintain concentration under permissible level (Sivaperumal et al. 2007; Uysal et al. 2008; Palaniappan and Karthikeyan 2009; Dehghani et al. 2017; Pal et al. 2018). Heavy metal pollution is increasingly recognized as a serious, environmental issue by environmentalists, high levels of toxicity, persistence, and potential for accumulation inside human body pose a serious health threat to the residents of urban areas (Karim et al. 2015; Mohmad et al. 2015; Hwang et al. 2016; Gope et al. 2017; Khan and Strand 2018; You et al. 2018; Liu et al. 2019; Men et al. 2019; Tian et al. 2019).

Many organizations and institutions such as the Food and Agriculture Organization (FAO), World Health Organization (WHO) and European Union (EU) from different countries have been established about the maximum permitted concentration of heavy metals in foodstuffs including fish and other seafood (Chary et al. 2008; Xue et al. 2012). For example, European Union (2006) reported that the maximum tolerable limit (MTL) of lead $(\mathrm{Pb})$ in the edible tissues of fish is $0.3 \mathrm{mg} / \mathrm{kg}$ where $\mathrm{Cd}$ and $\mathrm{Hg}$ were about $0.05-0.30$ and $0.5-1.00 \mathrm{mg} / \mathrm{kg}$ wet weight respectively depends on the type of fish. Heavy metals such as $\mathrm{Pb}, \mathrm{Cd}$ and $\mathrm{Hg}$ are categorized as nonessential elements and they are very toxic and harmful to individuals and aquatic organisms, even at small levels (Thomas et al. 2009; Zheng et al. 2011; Bourliva et al. 2018). While, $\mathrm{Zn}, \mathrm{Mn}, \mathrm{Cu}$, and $\mathrm{Ni}$ are essential elements due to their important function in biological systems (Stern et al. 2007; Fernandes et al. 2008). The dose-response curve for essential metals is U-shaped due to those metals that have both deficiency and copper excess which produce adverse health (Stern et al. 2007). 
Table 1. Sources of heavy metal contaminations in the aquatic environment (Lone et al. 2008; Changfeng et al. 2019)

\begin{tabular}{|c|c|}
\hline $\begin{array}{l}\text { Heavy } \\
\text { metals }\end{array}$ & Sources \\
\hline $\mathrm{Zn}$ & $\begin{array}{l}\text { Electroplating industry, smelting and refining, mining, } \\
\text { biosolids }\end{array}$ \\
\hline $\mathrm{Fe}$ & $\begin{array}{l}\text { Iron alloys are processed to containers, cars, laundry } \\
\text { machines, bridges, buildings, and also the other sources } \\
\text { of iron as pharmaceutics, chemicals, iron fertilizers, and } \\
\text { pesticides. }\end{array}$ \\
\hline $\mathrm{Cu}$ & $\begin{array}{l}\text { Electroplating industry, mining, biosolids, smelting, and } \\
\text { refining }\end{array}$ \\
\hline $\mathrm{Pb}$ & $\begin{array}{l}\text { Mining and smelting of metalliferous ores, burning of } \\
\text { leaded gasoline, municipal sewage, industrial wastes } \\
\text { enriched in } \mathrm{Pb} \text {, paints }\end{array}$ \\
\hline $\mathrm{Cd}$ & $\begin{array}{l}\text { Geogenic sources, anthropogenic activities, metal } \\
\text { smelting and refining, fossil fuel burning, application of } \\
\text { phosphate fertilizers, sewage sludge. }\end{array}$ \\
\hline $\mathrm{Hg}$ & $\begin{array}{l}\text { Volcano eruptions, forest fire, emissions from industries } \\
\text { producing caustic soda, coal, peat, and wood burning }\end{array}$ \\
\hline As & $\begin{array}{l}\text { Semiconductors, wood preservatives, mining and } \\
\text { smelting, coal power plants, herbicides, volcanoes, } \\
\text { petroleum refining, animal feed additives }\end{array}$ \\
\hline $\mathrm{Cr}$ & Electroplating industry, sludge, solid waste, tanneries \\
\hline $\mathrm{Mn}$ & $\begin{array}{l}\text { Municipal wastewater discharges, sewage sludge, } \\
\text { mining and mineral processing, emissions from alloy, } \\
\text { steel, and iron production, combustion of fossil fuels } \\
\text { and to a much lesser extent. }\end{array}$ \\
\hline $\mathrm{Ni}$ & $\begin{array}{l}\text { Volcanic eruptions, landfill, forest fire, bubble bursting } \\
\text { and gas exchange in ocean, weathering of soils and } \\
\text { geological materials, industrial effluents, kitchen } \\
\text { appliances, surgical instruments, steel alloys, } \\
\text { automobile batteries }\end{array}$ \\
\hline
\end{tabular}

Many organizations and institutions such as the Food and Agriculture Organization (FAO), World Health Organization (WHO) and European Union (EU) from different countries have been established about the maximum permitted concentration of heavy metals in foodstuffs including fish and other seafood (Chary et al. 2008; Xue et al. 2012). For example, European Union (2006) reported that the maximum tolerable limit (MTL) of lead $(\mathrm{Pb})$ in the edible tissues of fish is $0.3 \mathrm{mg} / \mathrm{kg}$ where $\mathrm{Cd}$ and $\mathrm{Hg}$ were about $0.05-0.30$ and $0.5-1.00 \mathrm{mg} / \mathrm{kg}$ wet weight respectively depends on the type of fish. Heavy metals such as $\mathrm{Pb}, \mathrm{Cd}$, and $\mathrm{Hg}$ are categorized as nonessential elements and they are very toxic and harmful to individuals and aquatic organisms, even at small levels (Thomas et al. 2009; Zheng et al. 2011; Bourliva et al. 2018). While, $\mathrm{Zn}, \mathrm{Mn}, \mathrm{Cu}$, and $\mathrm{Ni}$ are essential elements due to their important function in biological systems (Stern et al. 2007; Fernandes et al. 2008). The dose-response curve for essential metals is U-shaped due to those metals that have both deficiency and copper excess which produce adverse health (Stern et al. 2007).

$\mathrm{Zn}$ is a ubiquitous trace element and one of the essential elements that important to humans and plants. $\mathrm{Zn}$ is known as a cofactor to more than 300 enzymes that involved in RNA and DNA metabolism, and it is also important in the structural stabilization of a large amount of proteins (Song et al. 2010; Chasapis et al. 2012). When exceeding amounts are present, Zn becomes toxic (Krishna et al. 2014; Kastury et al. 2017) but a deficiency of $\mathrm{Zn}$ can lead to several disorders (Scherz and Kirchhoff 2006). such as results in poor pregnancy outcomes (King 2000; Uriu-adams and Keen 2010) and development of chronic diseases, including cardiovascular disease (Messner et al. 2009; Afridi et al. 2011) and also cause cancer (Kazi et al. 2010).

$\mathrm{Fe}$ is essential element for every living cell and necessary for the synthesis of many enzymes, myoglobin, and hemoglobin in the blood. The result deficiency of iron can lead to weakness, susceptibility, and inability to concentrate and other symptoms (Akoto et al. 2014). Anderson and Fitzgerald (2010) reported that one of the most common nutrient deficiencies in the world is $\mathrm{Fe}$ deficiency in anemia such as malaria. Anaemia disease gives poor performance in circulatory transport and also reduces oxygen supply to muscle, less efficiency due to the decreasing of myoglobin content and impairing endurance capacity (Erdman et al. 2012).

$\mathrm{Cu}$ is an essential metal of enzymes and necessary for hemoglobin synthesis (Sivaperumal et al. 2007). Impaired delivery of $\mathrm{Cu}$ can result in decreased cuproenzyme activity, the skeletal and vascular systems Failla et al. (2001), and also cause anemia, neutropenia, and osteoporosis (Angelova et al. 2011). Impaired metabolism of $\mathrm{Cu}$ could cause two genetic diseases which are Mense disease and Wilson disease. Accumulation of $\mathrm{Cu}$ can expose to the Mense disease which is a fatal disorder $(\mathrm{Gu}$ et al. 2002; Ameh and Sayes 2019). Wilson disease also could occur due to $\mathrm{Cu}$ accumulates in the brain and eyes in the form of Kayaer-Fleischer ring (Sarkar 1999; Attri et al. 2006). Excessive intake of $\mathrm{Cu}$ also could cause kidney damage and even death (U.S. Department of Health and Human Services 2004).

$\mathrm{Mn}$ has a biological significance due to its ability to prevent heart attack, stroke, and cardiac arrest, which is also an element of low toxicity. Deficiency of manganese can lead to poor growth performance, congenital malformations in offspring, and low efficiency of the reproductive system (Goldhaber 2003). However, it's become dangerous and toxic at high concentrations and usually may lead to neurologic and psychologic disorders (Perl and Olanow 2007; Saha and Zaman 2013). Normally, nickel (Ni) is an essential metal and occurs at very low levels in the environment. However, a deficiency of $\mathrm{Ni}$ in humans has not yet been reported and documented (Barceloux 1999). $\mathrm{Ni}$ is known to be carcinogenic (Salnikow and Kasprzak, 2005). Moreover, fibrosis, tumors, lung inflammation, and emphysema occur also caused by Ni (Forti et al. 2011).

$\mathrm{Cr}$ is an essential trace element in some aquatic animals and humans. Cr may reduce body fat and also improve lean body mass. However, their effects are small compared to those of a well-balanced diet and exercise (Roussel et al. 2007; Tulasi and Rao 2014). But it could have an undesirable fatal effect in excess amount. Lack of $\mathrm{Cr}$ can affect the growth and disturbances in glucose, lipid, and protein metabolism (Akoto et al. 2014). According to Stipanuk and Caudill (2012), they found that 12 out of 15 
studies showed a positive effect on the relationship between $\mathrm{Cr}$ and impaired glucose tolerance based on a meta-analysis.

Besides, $\mathrm{Hg}$ is a non-essential element. The levels of $\mathrm{Hg}$ increase due to the increases in fish size (Burger and Gochfeld 2011). Toxicity of $\mathrm{Hg}$ can damage the organ in fish (Sary and Mohammadi 2011; Krishna et al. 2014; AbuDieyeh et al. 2018). While, in humans, $\mathrm{Hg}$ can cause the development of fetus destroyed due to their toxicity and also considered as a carcinogen (Ikem and Egilla 2008). While, Vettori et al. (2003) studied that neuronal loss in the cerebellum granule layer and damage of discrete visual cortex area occurs in adult brain due to $\mathrm{Hg}$ poisoning. Emami-Khansari et al. (2005) also stated that $\mathrm{Hg}$ is a human toxicant and become primary source of human by eating fish.

Food consumption is the main source of exposure cadmium $(\mathrm{Cd})$ in the human body. $\mathrm{Cd}$ is known as an endocrine disturbing substance and it is well documented that $\mathrm{Cd}$ can cause to develop breast cancer and prostate cancer in humans (Saha and Zaman 2013). Cd also causes damage in kidney, hypertension, tumors, poor reproductive performance, and hepatic dysfunction (Rahman and Islam 2010; Al-Busaidi et al. 2011; Hao et al. 2013).

In addition, lead $(\mathrm{Pb})$ is a naturally-occurring and industrially-produced element that is very toxic to the human, especially children (Koyashiki et al. 2010; Kastury et al. 2019). Children are the most vulnerable to $\mathrm{Pb}$ because having less effective renal excretion and greater absorption of gastrointestinal. The fetal brain presents a greater sensitivity to the toxic effects of $\mathrm{Pb}$ compared to the mature brain (Schnaas et al. 2006). Umar et al. (2001) stated that symptoms of intestinal cramps, anemic condition and fatigue caused by poisoning of $\mathrm{Pb}$. Lead also can cause nephrotoxicity and neurotoxicity (García-lestón et al. 2010).

Nowadays, Arsenic (As) is widely spread in the environment due to both natural and anthropogenic processes (Rahman et al. 2012). As is a carcinogen and potent toxicant. As also has potential to destroy communities of ecological systems (Sadiq et al. 2003). Toxicity of as depends on the speciation (Devesa et al. 2008) and trivalent as (III) has the greatest toxicity. According to ATSDR (2000), mono and dimethyl arsenic have low toxicity.

\section{STUDIES ON HEAVY METALS IN FISH AND OTHER AQUATIC ORGANISMS IN KARACHI COAST}

Pakistan has geologically and ecologically diverse coastline dissected by harbors, estuaries, bays, and creeks exhibiting wide characteristics in the marine species. Unfortunately, the littoral state of Pakistan is facing many environmental issues as increasing pollution and humaninduced environmental changes particularly fishing, coastal aquaculture, waste disposal, industrial activity, agriculture, domestic effluents, salt making, unplanned tourism, etc. Contaminated ecosystem destroys the life of aquatic animals and decreases the market value of seafood products and increase in bacterial diseases (Kamal et al. 2015b; Shahab et al. 2016; Ahmed et al. 2017a; Chandio et al. 2018; Ahmed et al. 2019).

Karachi coast is a very important coast for its dimensions and economic activity. There are over 11000 industrial units (CDGK 2012) present, more than 2000 units in Federal-B-Area, 2571 units in Korangi zone, 2000 units in North Karachi, 1200 units in Landhi zone, and 4000 units in Mangopir zone in Karachi (Aziz and Khan 2014; Ahmed et al. 2018c; Mujeeb et al. 2020) Figure 1. By the Karachi coastline ever-growing pollution level, which is linked to the increase of the shipping industry through the Karachi port, is severely contaminating the mangrove, forests, and marine life (Ahmed et al. 2018c; Ali et al. 2019). The dumping of wastes on the coast provides a major source of heavy metal input (Khattak et al. 2012; Mukhtar and Hannan 2012; Chaudhary et al. 2013; Ahmed et al. 2018c). The important sources of heavy metals pollution are industrial activities and dumping of landbased wastes into the river and coasts of the sea. Especially in Pakistan and other countries such as India and Bangladesh most industries are converged on the riverbanks of big cities (Khan et al. 2011; Hasan et al. 2013; Jilani 2015; Hossain and Islam 2019). Not only these countries but all the coastal countries are exposed to heavy metal pollution. In the coastal areas, heavy metal contamination is found in seawater, sediment and aquatic organisms, causing a health risk (Kazmi and Zubair 2014; Elahi et al. 2015; Devault et al. 2017; Ahmed et al. 2018c).

The investigation of heavy metals ( $\mathrm{Zn}, \mathrm{Fe}, \mathrm{Cu}, \mathrm{Cd}, \mathrm{Hg}$, As, $\mathrm{Cr}, \mathrm{Ma}$ and $\mathrm{Ni}$ ) in different aquatic organisms on Karachi coast has been reported in numerous earlier studies such as Thunnus spp. (Yousuf and Ahmed 2010; Ahmed et al. 2012; Ahmed et al. 2015a), Pongamia pinnata (Shafiq et al. 2012), Fenneropenaeus penicillatus (Kamal et al. 2015a), Rastrelliger kanagurta (Yousuf and Ahmed 2011; Ahmed et al. 2014a; Ahmed and Bat 2015; Ahmed et al. 2016b), Holothurians spp. (Ahmed et al. 2017b; Ahmed et al. 2018b), Ohshimella ehrenbergii and Stolus buccalis (Ahmed et al. 2019) (Table 2, Figure 2). Heavy metals are being utilized in a variety of ways in industries, agriculture, food processing and household in many forms. The present study deals with the findings of various investigators on the effect of heavy metals on fish and other aquatic organisms in Karachi. The polluted areas (rivers and Karachi coast) receive effluents from industrial, agricultural, municipal and domestic sources (Ali et al. 2014; Iftikhar et al. 2018). The order of abundance of the metals were as fellow; $\mathrm{Fe}>$ $\mathrm{Zn}>\mathrm{Cu}>\mathrm{Mn}>\mathrm{Cd}>\mathrm{Pb}>\mathrm{Cr}>\mathrm{Ni}>\mathrm{Hg}>\mathrm{As} . \mathrm{Pb}$ is a neurotoxic metal that causes many behavioral defects in biotic samples, as a result of which decrease in survival growth rates and metabolism occur. The main source of $\mathrm{Pb}$ in the present geographical locale could be the contamination from Ibrahim Hyderi coast. The discharge of industrial waste of Korangi industrial trading estate (KITE) and Gizri Creek causes the increase $\mathrm{Pb}$ concentration along with the littoral states of Ibrahim Hyderi (Khwaja et al. 2012; Kamal et al. 2015a). 


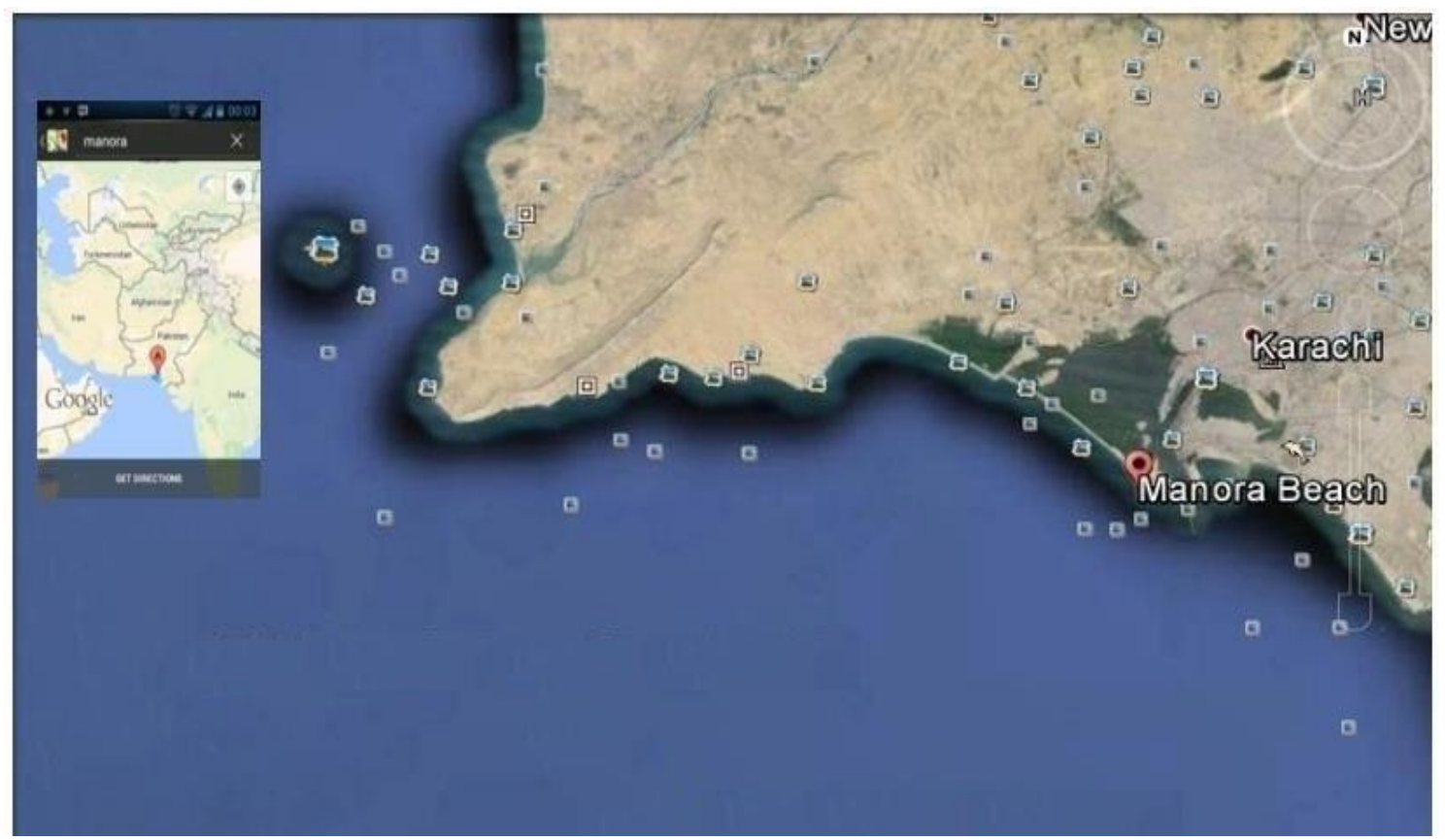

Figure 1. Map of the study area in Karachi Coast, Pakistan

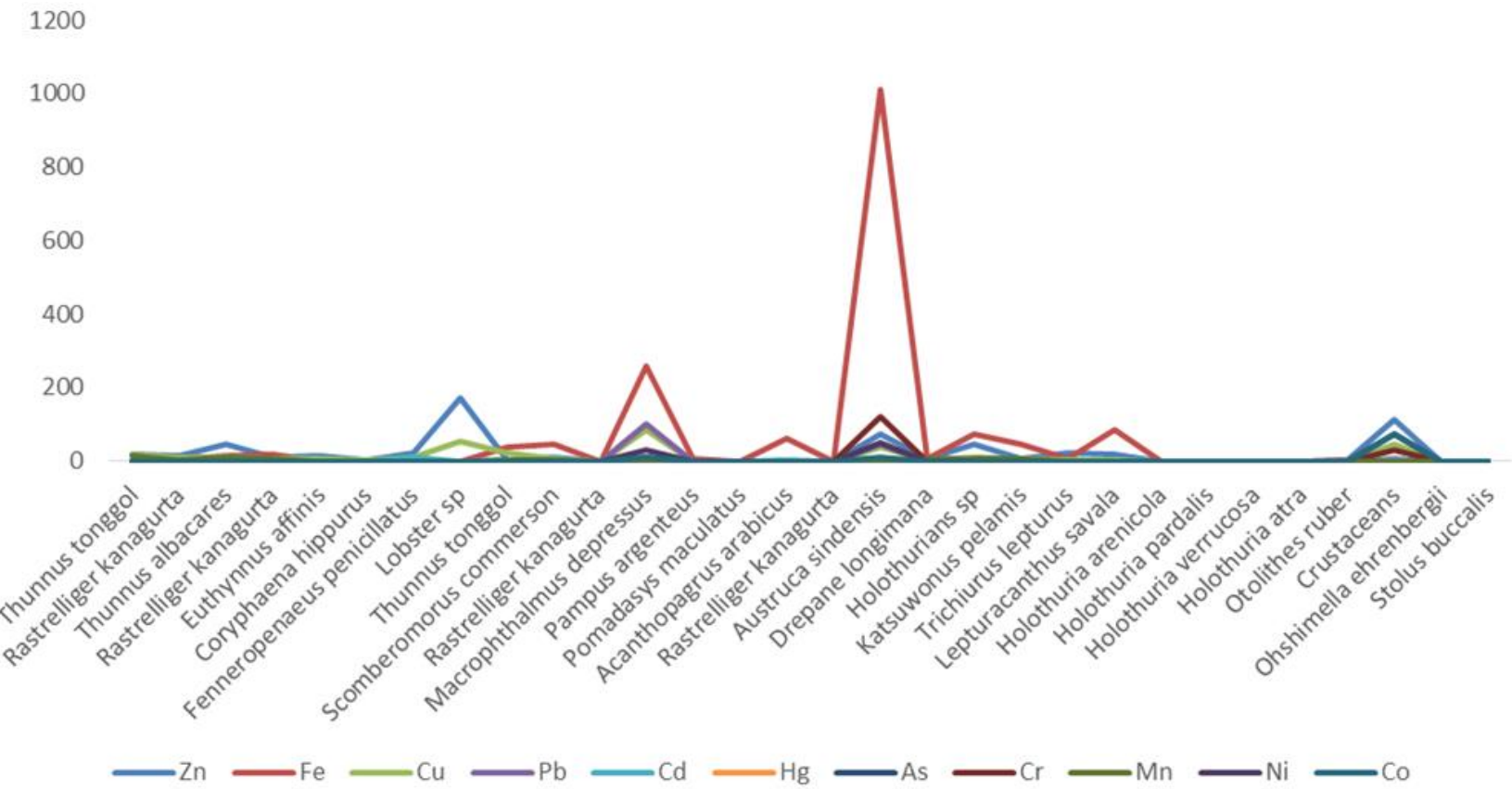

Figure 2. Accumulation of heavy metals $(\mathrm{mg} / \mathrm{kg})$ in fish and other aquatic organisms, Karachi Coast, Pakistan

Heavy metal loaded aquatic systems may affect the food chain of inhabitant fish species. It is reported by many researchers that heavy metal pollution in aquatic ecosystems is often more reflected by high metal levels in sediments, macrophytes, and benthic animals than by elevated concentrations in water (Van Hassel et al. 1980; Ashraf et al. 2019). Heavy metal accumulation and its effects on fish are very much complex to elucidate because of dynamic nature of aquatic ecosystems.

Aquatic animals mainly the phyla crustacean species are the bio-indicators of toxic materials because invertebrates have more tendencies to accumulate contaminants as compare to fishes (Balfour et al. 2012; Kamal et al. 2015b; Ahmed et al. 2017a). Hazardous material from the surrounding continuously enter in fresh and marine environment and deposit in biota from where it subsequently transferred in to human through the food chain and when the concentration of these substances reaches to a certain level, it becomes toxic (Gokoglu et al. 2008; Copat et al. 2013; Goretti et al. 2016). 
Table 2. Levels of heavy metal in edible tissue of fish and other aquatic organisms from Karachi Coast, Pakistan

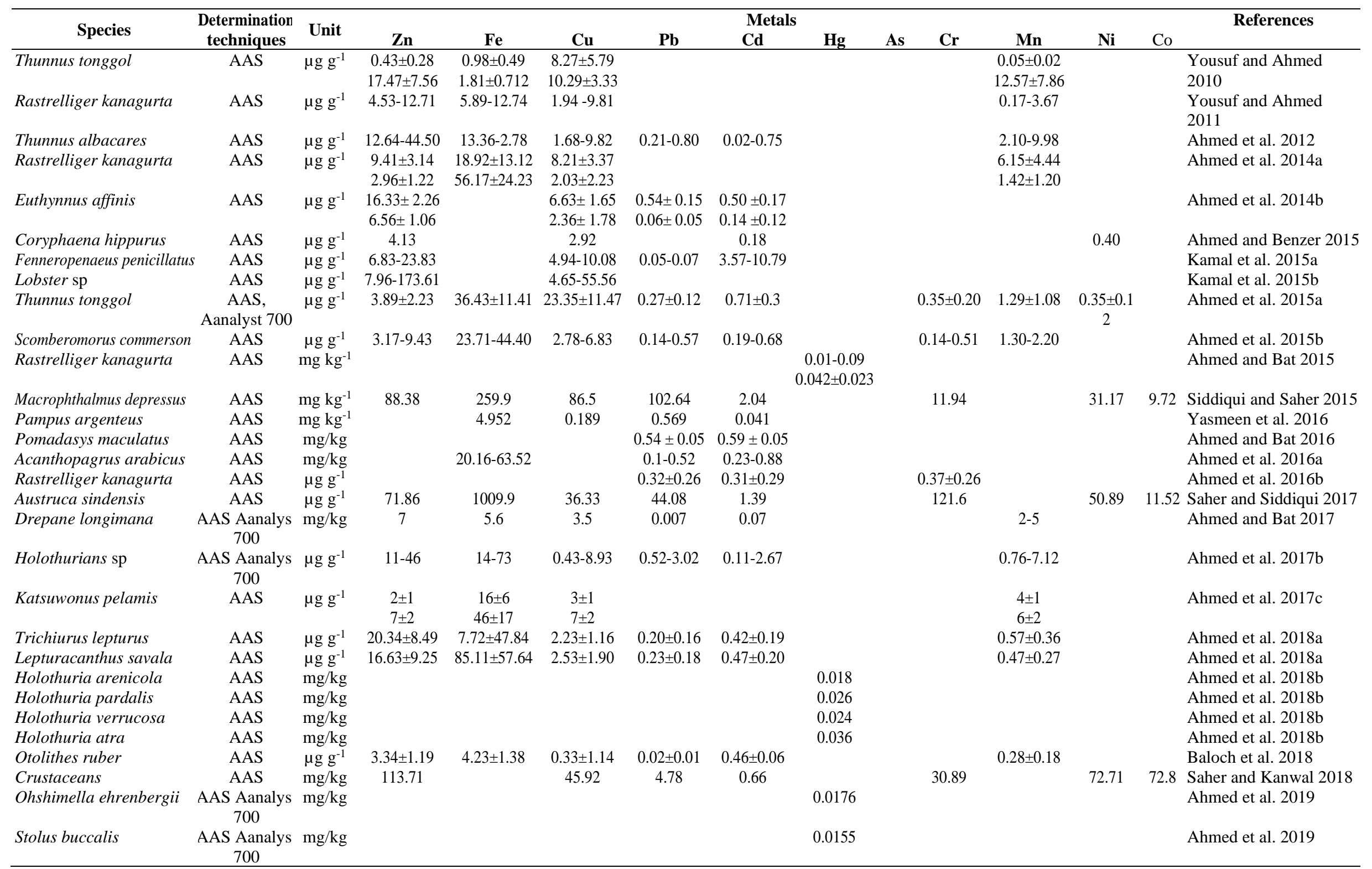


International limits

WHO

FAO

USA

European Community

England

EU lmits

\begin{tabular}{|c|c|c|c|}
\hline 40 & 100 & 30 & 2 \\
\hline 30 & - & 30 & $0.5-6$ \\
\hline 75 & 11 & 6 & 1 \\
\hline- & - & - & 0.2 \\
\hline 50 & - & 20 & 2 \\
\hline - & - & 10 & 0.1 \\
\hline
\end{tabular}

WHO 1989

FAO 1983

Cohen et al. 2001

EC 2005

MAFF 2000

EU 2001 
Previous investigations have shown declined condition of aquatic environment on Karachi coast, due to heavy metals contamination which is one of the most critical environmental issues in Pakistan and worldwide (Shaheen et al. 2016). The main source of $\mathrm{Cu}$ and $\mathrm{Zn}$ metals in the present geographical location could be the effluents of Bin Qasim thermal power plants, seaport activities, industrial effluents of SITE (Sindh Industrial Trade Estate) through Layari River, and unloading of raw materials for Pakistan steel mill; which is further fractionated into water, seaweed and sediments. Industrial effluents coming through Malir River, sewage water and oil refinery situated in the coastal region are the other sources of $\mathrm{Cu}$ and $\mathrm{Zn}$ contamination (Kamal et al. 2015a; Shahid et al. 2016).

Major source of copper contamination in marine organisms is via food chain rather seawater. Thus increasing ambient pollution levels in water do not directly affects the marine life. Copper is considered highly toxic metal after mercury and silver for marine life because of the existence of a number of detoxifying and storage systems for $\mathrm{Cu}$ (Mitra et al. 2012).

Cadmium is mainly concerned pollutant because it is very much toxic metal to aquatic organisms. Cadmium is absorbed in excess by human being through seafood and tends to accumulate mainly in liver and kidneys (Kamal et al. 2015; Ahmed et al. 2018a). The main source of cadmium contamination along the coastal areas is electroplating and industrial waste because it is an important metal with industrial applications.

This review was carried out to provide information on heavy metal concentrations in fish and other aquatic organisms on Karachi coast, Pakistan. The findings of various investigators on the effect of heavy metals on fish and other aquatic organism in Karachi were as follow; $\mathrm{Fe}>$ $\mathrm{Zn}>\mathrm{Cu}>\mathrm{Mn}>\mathrm{Cd}>\mathrm{Pb}>\mathrm{Cr}>\mathrm{Ni}>\mathrm{Hg}>\mathrm{As}$. Fish and other aquatic organisms are used as a bio-indicator to evaluate the health of aquatic ecosystems since heavy metals accumulate in food, that it would be useful to carry out in detailed, extensive observations to monitor this situation in the future in (Rivers and Karachi coast) especially around the industrial, agricultural, municipal and domestic and polluted areas and their impact on the environment.

\section{ACKNOWLEDGEMENTS}

The authors are thankful to the Director International Center for Chemical and Biological Sciences, University of Karachi, Pakistan for providing necessary laboratory facilities, and also our thanks extend to Sudan University of Science \& Technology and Ministry of Higher Education \& Scientific Research-Sudan. We also gratefully acknowledge the financial assistance from TWAS World Academy of Sciences, Trieste, Italy (TWAS-ICCBS PostDoctoral Fellowship No. RF 3240305609) awarded to Dr. Ramzy A. Yousif.

\section{REFERENCES}

Abarshi MM, Dantala EO, Mada SB. 2017. Bioaccumulation of heavy metals in some tissues of croaker fish from oil spilled rivers of Niger Delta region, Nigeria. Asian Pac J Trop Biomed 7: 563-568.

Abu-Dieyeh MH, Usman K, Alduroobi H, Al-Ghouti M. 2018. Mercury toxicity: The importance of microbial diversity for improved environmental remediation. In: Donati ER (eds). Heavy Metals in the Environment. CRC Press, Boca Raton, Florida.

Afridi HI, Kazi TG, Kazi N, Kandhro GA, Baig JA, Jamali MK, Shah AQ. 2011. Interactions between cadmium and zinc in the biological samples of Pakistani smokers and nonsmokers cardiovascular disease patients. Biol Trace Elem Res 139: 257-268. DOI: 10.1007/s12011009-8607-3

Agency for Toxic Substances and Disease Registry. 2000. Toxicological Profile for Arsenic. Department of Health and Human Services, Public Health Service, Atlanta, US.

Ahmed Q, Bat L, Mohammad Ali Q. 2012. Heavy metal levels in Thunnus albacares (Bonnaterre, 1788) from Karachi fish harbour, Pakistan. Pak J Mar Sci 21(1 and 2): 13-21.

Ahmed Q, Yousuf F, Sarfraz M, Abu Bakar NK, Balkhour MA, Ashraf MA. 2014a. Seasonal elemental variations of $\mathrm{Fe}, \mathrm{Mn}, \mathrm{Cu}$ and $\mathrm{Zn}$ and conservational management Rastrelliger kanagurta fish from Karachi fish harbour, Pakistan. J Food Agric Environ 12 (3\&4): 405-414.

Ahmed Q, Yousuf F, Sarfraz M, Ali QM, Balkhourd M, Safie SZ, Ashraf MA. 2014b. Euthynnus affinis (little tuna): Fishery, bionomics, seasonal elemental variations, health risk assessment and conservational management. Front Life Sci 8: 71-96. DOI: $10.1080 / 21553769.2014 .961617$

Ahmed Q, Benzer S. 2015. Heavy metal concentration in dolphinfish (Coryphaena hippurus Linnaeus, 1758) from Karachi Harbour, Pakistan. IJFAS 2 (5): 26-29.

Ahmed Q, Bat L. 2015. Mercury $(\mathrm{Hg})$ levels in Indian mackerel Rastrelliger kanagurta (Scombridae) from Karachi fish harbour and its risk assessment. J Fish Sci 9 (1): 356-360. DOI: 10.3153/jfscom.201444

Ahmed Q, Bat L, Yousuf F. 2015. Accumulation of heavy metals in tissues of long tail tuna from Karachi Fish Harbour, Pakistan. Aquat Sci Technol 3 (1): 103-115. DOI: 10.5296/ast.v3i1.6814

Ahmed Q, Bat L, Yousuf F, Ali QM, Nazim K. 2015b. Accumulation of heavy metals ( $\mathrm{Fe}, \mathrm{Mn}, \mathrm{Cu}, \mathrm{Zn}, \mathrm{Ni}, \mathrm{Pb}, \mathrm{Cd}$ and $\mathrm{Cr}$ ) in Tissues of narrow-barred Spanish mackerel (Family-Scombridae) fish marketed by Karachi Fish Harbor. Open Biol Sci J 1: 20-28. DOI: $10.2174 / 2352633501501010020$

Ahmed Q, Bat L. 2016. Levels and health risk assessments of $\mathrm{Cd}$ and $\mathrm{Pb}$ in Pomadasys maculatus marketed by Karachi Fish Harbor, Pakistan. Ilmu Kelautan 21 (2): 53-58. DOI: 10.14710/ik.ijms.21.2.53-58

Ahmed Q, Bat L, Yousuf F, Aric1 E. 2016. Heavy metals in Acanthopagrus arabicus Iwatsuki, 2013 from Karachi Coasts, Pakistan and potential risk of human health. Int J Fish Aquat Stud 4 (1): 203-208

Ahmed Q, Benzer S, Yousuf F. 2016b. Distribution of heavy metals in different tissues of Indian mackerel from Karachi fish harbour, Karachi, Pakistan. Indian J Anim Res 50 (5): 759-763. DOI: 10.18805/ijar.11423

Ahmed Q, Bat L. 2017. Heavy metal levels in different sizes and tissues of Drepane longimana (Bloch \& Schneider, 1801) from Arabian Sea. J Coast Life Med 5 (12): 505-509. DOI: 10.12980/jclm.5.2017J7-148

Ahmed Q, Ali QM, Bat L, Ghory FS. 2017a. Concentration of heavy metals in red, brown and green algae collected from the Karachi Coast of Pakistan. Pak J Mar Sci 26 (1\&2): 57-65.

Ahmed Q, Ali QM, Bat L. 2017b. Assessment of heavy metals concentration in holothurians, sediments and water samples from coastal areas of Pakistan (Northern Arabian Sea). J Coast Life Med 5 (5): 191-201. DOI: 10.12980/jclm.5.2017J7-56

Ahmed Q, Bat L, Yousuf F. 2017c. Contamination of Cu, Zn, Fe and Mn in Katsuwonus pelamis (Linnaeus, 1758) from Karachi fish harbor and potential risks to human health. Int J Mar Sci 7 (9): 76-87. DOI: 10.5296/ast.v3i1.681410.5376/ijms.2017.07.0009

Ahmed Q, Benzer S, Ali QM. 2018a. Heavy metal concentration in Largehead Hairtail (Trichiurus lepturus Linneaus, 1758) and Savalai Hairtail (Lepturacanthus savala (Cuvier, 1829)) obtained from Karachi Fish Harbour, Pakistan. Bull Environ Contam Toxicol 101 (4): 467-472. DOI: $10.1007 / \mathrm{s} 00128-018-2418-1$ 
Ahmed Q, Bat L, Ali QM. 2018b. Analysis of mercury (Hg) in four Holothurians species (Phylum Echinodermata) from Karachi Coast Northern Arabian Sea. Aquat Res 1 (2): 55-63. DOI: 10.3153/AR18007

Ahmed Q, Bat L, Öztekin A, Mohammad Ali Q. 2018c. A review on studies of heavy metal determination in Mackerel and Tuna (FamilyScombridae) fishes. J Anatolian Env Anim Sci 3 (3): 104-120.

Ahmed Q, Bat L, Ali MQ. 2019. Determination of mercury (Hg) in two Sea Cucumber species Ohshimella ehrenbergii (Selenka, 1868) and Stolus buccalis (Stimpson, 1855) from The Karachi Coast. Pak J Mar Sci 28 (1): 55-62.

Akoto O, Bismark Eshun F, Darko G, Adei E. 2014. Concentrations and health risk assessments of heavy metals in fish from the Fosu Lagoon. Int J Environ Res 8 (2): 403-410.

Al-Busaidi M, Yesudhason P, Al-Mughairi S, Al-Rahbi WA, Al-Harthy K, Al-Mazrooei N. 2011. Chemosphere toxic metals in commercial marine fish in oman with reference to national and international standards. Chemosphere 85 (1): 67-73. DOI: 10.1016/j.chemosphere.2011.05.057

Ali M, Adnan M, Noman S, Baqueri S. 2014. Estimation of tract congestion cost-A case study of a major arterial in Karachi. Proc Eng 77: $37-44$.

Ali AA, Elazein EM, Alian MA. 2011. Investigation of heavy metals pollution in water, sediment and fish at Red Sea-Jeddah Coast-KSA at two different locations. J Appl Environ Biol Sci 1: 630-637.

Ali N, Khan MU, Khoso SA. 2019. Identification of biological threats zones along the coastline of Karachi. Int J Environ Sci Tech 16 (7): 3557-3564. DOI: 10.1007/s13762-018-1884-7

Alinnor I, Obiji I. 2010. Assessment of trace metal composition in fish samples from Nworie River. Pak J Nutr 9 (1):81-85. DOI $10.3923 /$ pjn. 2010.81 .85

Ameh T, Sayes C.M. 2019. The potential exposure and hazards of copper nanoparticles: A review. Environ Toxicol Pharmacol 71: 103220 DOI: $10.1016 /$ j.etap.2019.103220

Anderson J, Fitzgerald C. 2010. Iron: An Essential Nutrient Review. [Online]. http://www.ext.colostate.edu/pubs/foodnut/09356.html

Angelova M, Asenova S, Nedkova V, Koleva-Kolarova R. 2011. Copper in the human organism. Trakia J Sci 9 (1): 88-98.

Arulkumar A, Paramasivam S, Rajaram R. 2017. Toxic heavy metals in commercially important food fishes collected from Palk Bay, Southeastern India. Mar Pollut Bull 119 (1): 454-459. DOI: 10.1016/j.marpolbul.2017.03.045

Ashraf S, Ali Q, Zahir ZA, Ashraf S, Asghar HN. 2019. Phytoremediation: Environmentally sustainable way for reclamation of heavy metal polluted soils. Ecotoxicol Environ Saf 174: 714-727. DOI: $10.1016 /$ j.ecoenv.2019.02.068

Atafar Z, Mesdaghinia A, Nouri J, Homaee M, Yunesian M, Ahmadimoghaddam M, Mahvi AH. 2010. Effect of fertilizer application on soil heavy metal concentration. Environ Monit Assess 160 (1-4): 83-89. DOI: $10.1007 / \mathrm{s} 10661-008-0659-\mathrm{x}$

Ates A, Türkmen M, Tepe Y. 2015. Assessment of heavy metals in fourteen marine fish species of four Turkish seas. Indian J Mar Sci 44 (1): 49-55.

Attri S, Sharma N, Jahagirdar S, Thapa BR, Prasad R. 2006. Erythrocyte metabolism and antioxidant status of patients with Wilson disease with hemolytic anemia. Pediatr Res 59 (4): 593-597. DOI: 10.1203/01.pdr.0000203098.77573.39

Aziz I, Khan F. 2014. Distribution, ecology \& ecophysiology of mangroves in Pakistan. In: Khan MA, Böer B, Öztürk M, A Abdessalaam TZ, Clüsener-Godt M, Gul B. Sabkha Ecosystems Vol IV: Cash Crop Halophyte \& Biodiversity Conservation. Springer, Berlin, Germany.

Baki MA, Hossain MM, Akter J, Quraishi SB, Shojib MFH, Ullah AKMA, Khan MF. 2018. Concentration of heavy metals in seafood (fishes, shrimp, lobster and crabs) and human health assessment in Saint Martin Island, Bangladesh. Ecotoxicol Environ Saf 159: 153163.

Balfour S, Badrie N, Yen IC, Chatergoon L. 2012. Seasonal influence and heavy metal analysis in marine shrimp (Penaeus spp.) sold in Trinidad, Westindies. J Food Res 1 (1): 193-199. DOI: 10.5539/jfr.v1n1p193

Baloch AB, Bat L, Ali QM, Ahmed Q. 2018. Concentration of heavy metals $(\mathrm{Fe}, \mathrm{Zn}, \mathrm{Mn}, \mathrm{Cu}, \mathrm{Pb}$ and $\mathrm{Cd}$ ) in Otolithes ruber (Bloch \& Schneider, 1801) from damb fish landing centre at Sonmiani, Makran Coast, Pakistan. Pak J Mar Sci 27 (2): 111-119.
Barceloux DG. 1999. Nickel. Clin Toxicol 37: 239. DOI: 10.1081/CLT100102423

Bourliva A, Kantiranis N, Papadopoulou L, Aidona E, Christophoridis C, Kollias P, Evgenakis M, Fytianos K. 2018. Seasonal and spatial variations of magnetic susceptibility and potentially toxic elements (PTEs) in road dust of Thessaloniki city, Greece: A one-year monitoring period. Sci Total Environ 639: 417-427. DOI: 10.1016/j.scitotenv.2018.05.170

Bryan G, Langston W. 1992. Bioavailability, accumulation and effects of heavy metals in sediments with special reference to United Kingdom estuaries: A review. Environ Pollut 76 (2): 89-131. DOI: 10.1016/0269-7491(92)90099-V

Burger J, Stern AH, Dixon C, Jeitner C, Shukla S, Burke S, Gochfeld M. 2004. Fish availability in supermarkets and fish markets in New Jersey. Sci Total Environ 333 (1-3): 89-97. DOI: 10.1016/j.scitotenv.2004.05.016

Burger J, Gochfeld M. 2011. Mercury and selenium levels in 19 species of saltwater fish from New Jersey as a function of species, size, and $\begin{array}{lllll}\text { season. Sci Total Environ 409: 1418-1429. DOI: } & \end{array}$ 10.1016/j.scitotenv.2010.12.034

Castro-gonzález MI, Méndez-armenta M. 2008. Heavy metals: Implications associated to fish consumption. Environ Toxicol Pharmacol 26: 263-271. DOI: 10.1016/j.etap.2008.06.001

CDGK. 2012. City District Government of Karachi. www.karachicity.gov.pk.

Chandio AA, Jiang Y, Rehman A. 2018. Credit margin of investment in the agricultural sector and credit fungibility: The case of smallholders of district Shikarpur, Sindh, Pakistan. Financ Innov 4: 27. DOI: 10.1186/s40854-018-0109-x

Changfeng L, Kehai Z, Wenqiang Q, Changjiu T, Miao Q, Xiaoming Y, Wenbing H. 2019. A review on heavy metals contamination in soil: Effects, sources, and remediation techniques. Soil Sediment Contam: An Int J 28: 380-394. DOI: 10.1080/15320383.2019.1592108

Chary NS, Kamala CT, Raj DSS. 2008. Assessing risk of heavy metals from consuming food grown on sewage irrigated soils and food chain transfer. Ecotoxicol Environ Saf 69 (3): 513-524. DOI: 10.1016/j.ecoenv.2007.04.013

Chasapis CT, Loutsidou A, Spiliopoulou CA, Stefanidou ME. 2012. Zinc and human health: An update. Arch Toxicol 86: 521-534. DOI: 10.1007/s00204-011-0775-1

Chaudhary MZ, Ahmad N, Mashiatullah A, Ahmad N, Ghaffar A. 2013. Geochemical assessment of metal concentrations in sediment core of Korangi Creek along Karachi Coast. Pak Environ Monit Assess 185: 6677-6691. DOI: 10.1007/s10661-012-3056-4

Chen ZF, Zhao Y, Fan LD, Xing LT, Yang YJ. 2015. Cadmium (Cd) localization in tissues of cotton (Gossypium hirsutum L.) and its phytoremediation potential for Cd-contaminated soils. Bull Environ Contam Toxicol 95: 784-789. DOI: 10.1007/s00128-015-1662-x

Chen J, Wang W, Liu H, Ren L. 2011. Determination of road dust loading and chemical characteristics using resuspension. Environ Monit Assess 184: 1693-1709.

Cid BP, Boia C, Pombo L, Rebelo E. 2001. Determination of trace metals in fish species of the Ria De Aveiro (Portugal) by electrothermal atomic absorption spectrometry. Food Chem 75 (1): 93-100. DOI: $10.1016 / \mathrm{S} 0308-8146(01) 00184-4$

Cohen T, Que Hee SS, Ambrose RF. 2001. Trace metals in fish and invertebrates of three California coastal Wetlands. Mar Pollut Bull 42: 224-232. DOI: 10.1016/S0025-326X(00)00146-6

Copat C, Arena G, Fiore M, Ledda C, Fallico R, Sciacca S, Ferrante M. 2013. Heavy metals concentrations in fish and shellfish from eastern Mediterranean Sea: Consumption advisories. Food Chem Toxicol 53: 33-37.

Daellenbach K, Stefenelli G, Bozzetti C, Vlachou A, Fermo P, Gonzalez R, Piazzalunga A, Colombi C, Canonaco F, Hueglin C. 2017. Longterm chemical analysis and organic aerosol source apportionment at 9 sites in Central Europe: Source identification and uncertainty assessment. Atmos Chem Phys Discus 17: 13265-13282.

DOI: $10.5194 / \mathrm{acp}-17-13265-2017$

Dehghani S, Moore F, Keshavarzi B, Hale B. 2017. Health risk implications of potentially toxic metals in street dust and surface soil of Tehran, Iran. Ecotoxicol Environ Saf 136: 92-103.

Devault DA, Beilvert B, Winterton P. 2017. Shipbreaking or scuttling? A review of environmental, economic and forensic issues for decision support. Environ Sci Pollut Res 24: 25741-25774. 
Devesa V, Velez D, Montoro R. 2008. Effect of thermal treatments on arsenic species contents in food. Food Chem Toxicol 46: 1-8. DOI: 10.1016/j.fct.2007.08.021

Elahi N, Ahmed Q, Bat L, Yousuf F. 2015. Physiochemical parameters and seasonal variation of coastal water from Balochistan Coast, Pakistan. J Coast Life Med 3 (3): 199-203. DOI: 10.12980/JCLM.3.201514J94

Emami-Khansari F, Ghazi-Khansari M, Abdollahi M. 2005. Heavy Metals content of canned tuna fish. Food Chem 93: 293-296. DOI: 10.1016/j.foodchem.2004.09.025

Erdman JW, Macdonald IA, Zeisel SH. 2012. Present Knowledge in Nutrition. $10^{\text {th }}$ edition. A John Wiley \& Sons, Ltd., Publication, New Jersey.

European Community EC. 2005. Commission Regulation No 78/2005 (pp L16/43-L16/45). Official Journal of the European Union. 20.1.2005.

European Union EU. 2001. Commission Regulation as regards heavy metals, Directive, 2001/22/EC, No: 466.

European Union EU. 2006. Setting Maximum Levels for Certain Contaminants in Foodstuffs, Commission Regulation (EC) No 1881/2006; OJ L 364, 20.12.2006. 5.

Failla ML, Johnson MA, Prohaska JR. 2001. Copper. In: Present Knowledge in Nutrition. Life Sciences Institute Press, Washington D.C.

FAO. 1983. Compilation of legal limits for hazardous substances in fish and fishery products. FAO Fish Circ 764: 5-100.

Fernandes C, Fontaínhas-Fernandes A, Cabral D, Salgado MA. 2008 Heavy metals in water, sediment and tissues of liza saliens from Esmoriz-Paramos Lagoon, Portugal. Environ Monit Assess 136 (1-3): 267-275. DOI: 10.1007/s10661-007-9682-6

Forti E, Salovaara S, Cetin Y, Bulgheroni A, Tessadri R, Jennings P, Prieto P. 2011. In vitro evaluation of the toxicity induced by nicke soluble and particulate forms in human airway epithelial cells Toxicol in Vitro 25 (2): 454-461. DOI: 10.1016/j.tiv.2010.11.013

García-lestón J, Mendez J, Pásaro E, Laffon B. 2010. Author's persona copy genotoxic effects of lead: An updated review. Environ Int 36 623-636. DOI: 10.1016/j.envint.2010.04.011

Gokoglu N, Yerlikaya P, Gokoglu M. 2008. Mini-Review: Trace element in edible tissues of three shrimp species (Penaeus semisulcatus, Parapenaeus longirostris, and Paleomon serratus). J Sci Food Agric 88: 175-178. DOI: $10.1002 /$ jsfa.3086

Goldhaber SB. 2003. Trace element risk assessment: Essentiality vs toxicity. Regul Toxicol Pharmacol 38: 232-242. DOI 10.1016/S02732300(02)00020-X

Gope M, Masto R, George J, Hoque R, Balachandran S. 2017. Bioavailability and health risk of some potentially toxic elements $(\mathrm{Cd}$ $\mathrm{Cu}, \mathrm{Pb}$ and $\mathrm{Zn}$ ) in street dust of Asansol, India. Ecotoxicol Environ Saf 138: 231-241.

Goretti E, Pallottini M, Ricciarini MI, Selvaggi R, Cappelletti D. 2016 Heavy metals bioaccumulation in selected tissues of red swamp crayfish: An easy tool for monitoring environmental contamination levels. Sci Total Environ 559: 339-346.

Gu Y, Kodama H, Sato E, Mochizuki D, Yanagawa Y, Takayanagi M, Lee C. 2002. Prenatal diagnosis of menkes disease by genetic analysis and copper measurement. Brain Develop 24: 715-718. DOI: 10.1016/S0387-7604(02)00093-1

Hao Y, Chen L, Zhang X, Zhang D, Zhang X, Yu Y, Fu J. 2013. Trace elements in fish from Taihu Lake, China: Levels, associated risks, and trophic transfer. Ecotoxicol Environ Saf 90: 89-97. DOI: 10.1016/j.ecoenv.2012.12.012

Hasan AB, Kabir S, Reza AS, Zaman MN, Ahsan A, Rashid M. 2013 Enrichment factor and geo-accumulation index of trace metals in sediments of the ship breaking area of Sitakund Upazilla (BhatiaryKumira), Chittagong, Bangladesh. J Geo Expl 125: 130-137.

Hossain M, Islam M. 2019. Ship breaking activities and its impact on the coastal zone of Chittagong. http://ypsa.org/publications/Impact.pdf

Hwang HM, Fiala M, Park D, Wade T. 2016. Review of pollutants in urban road dust and stormwater runo Part 1 . Heavy metals released from vehicles. Int J Urban Sci 20: 334-360.

Iftikhar M, Alam K, Sorooshian A, Syed WA, Bibi S, Bibi H. 2018. Contrasting aerosol optical and radiative properties between dust and urban haze episodes in megacities of Pakistan. Atmos Environ 173: 157-172.

Ikem A, Egilla J. 2008. Trace Element Content of Fish Feed and Bluegill Sunfish (Lepomis macrochirus) from aquaculture and wild source in Missouri. Food Chem 110 (2): 301-309. DOI 10.1016/j.foodchem.2008.02.003
Jibiri N, Adewuyi G. 2008. Radionuclide contents and physicochemical characterization of solid waste and effluent samples of some selected industries in the city of Lagos, Nigeria. Radioprot 43 (2): 203-212. DOI: $10.1051 /$ radiopro:2007053

Jilani S. 2015. Metal pollution and its distribution pattern in the road dust of Karachi. J Biodivers Environ Sci 6: 215-224.

Kamal T, Tanoli MAK, Mumtaz M, Ali N, Ayub S. 2015a. Bioconcentration potential studies of heavy metals in Fenneropenaeus penicillatus (Jaira or Red Tail Shrimp) along the Littoral States of Karachi City. J Basic Appl Sci 11: 611-618. DOI: 10.6000/1927-5129.2015.11.82

Kamal T, Tanoli MAK, Mumtaz M, Ali N, Ayub S. 2015b. Analysis of essential elements in commercially important lobster species collected from coastal areas of Karachi City, Pakistan. J Pharm Nutr Sci 5: 103113. DOI: 10.6000/1927-5951.2015.05.02.2

Karim Z, Qureshi BA, Mumtaz M. 2015. Geochemical baseline determination and pollution assessment of heavy metals in urban soils of Karachi, Pakistan. Ecol Indic 48: 358-364.

Kastury F, Smith E, Juhasz AL. 2017. A critical review of approaches and limitations of inhalation bioavailability and bioaccessibility of metal(loid)s from ambient particulate matter or dust. Sci Total Environ 574: 1054-1074.

Kastury F, Smith E, Doelsch E, Lombi E, Donnelley M, Cmielewski P, Parsons D, Scheckel K, Paterson D, de Jonge M. 2019. In vitro, in vivo, and spectroscopic assessment of lead exposure reduction via ingestion and inhalation pathways using phosphate and iron amendments. Environ Sci Technol 53 (17): 10329-10341. DOI: 10.1021/acs.est.9b02448

Kazi TG, Wadhwa SK, Afridi HI, Kazi N, Kandhro GA, Baig JA, Arain MB. 2010. Interaction of Cadmium and Zinc in biological samples of smokers and chewing tobacco female mouth cancer patients. J Hazard Mater 176: 985-991. DOI: 10.1016/j.jhazmat.2009.11.139

Kazmi J, Zubair S. 2014. Estimation of vehicle damage cost involved in road trac accidents in Karachi, Pakistan: A geospatial perspective. Proc Eng 77: 70-78.

Kennedy CJ. 2011. The toxicology of metals in fishes. In: Farrell AP (eds.) Encyclopedia of Fish Physiology: From Genome to Environment. Academic Press, San Diego, Calif, USA.

Khan R, Strand M. 2018. Road dust and its effect on human health: A literature review. Epidemiol Health 40: e2018013. DOI: 10.4178/epih.e2018013.

Khan I, Ghani A, Rehman AU, Awan SA, Noreen A, Khalid I. 2016. Comparative analysis of heavy metal profile of Brassica campestris (L.) and Raphanus sativus (L.) irrigated with municipal wastewater of Sargodha city. J Clin Toxicol 6: 1-4. DOI: 10.4172/21610495.1000307

Khan MN, Wasim AA, Sarwar A, Rasheed, MF. 2011. Assessment of heavy metal toxicants in the roadside soil along the N-5, National Highway, Pakistan. Environ Monit Assess 182: 587-595.

Khattak MI, Khattak MI, Mohibullah M. 2012. Study of heavy metal pollution in mangrove sediments reference to marine environment along the coastal areas of Pakistan. Pak J Bot 44 (1): 373-378.

Khwaja H, Fatmi Z, Malashock D, Aminov Z, Kazi A, Siddique A, Zeb J, Carpenter D. 2012. Effect of air pollution on daily morbidity in Karachi, Pakistan. J Local Glob Health Sci 3: 1-13.

King JC. 2000. Determinants of maternal zinc status during pregnancy. Am J Clin Nutr 71: 1334-1343. DOI: 10.1093/ajen/71.5.1334s

Koyashiki GAK, Paoliello MMB, Tchounwou PB. 2010. Lead levels in human milk and children's health risk: A systematic review. Rev Environ Health 25 (3): 243-253.

Krishna P, Jyothirmayi V, Madhusudhana Rao K. 2014. Human health risk assessment of heavy metal accumulation through fish consumption, from Machilipatnam Coast, Andhra Pradesh, India. Int Res J Public Environ Health 1 (5): 121-125.

Lambert M, Leven B, Green R. 2000. New methods of cleaning up heavy metal in soils and water. Environmental Science and Technology Briefs for Citizens, Kansas State University, Manhattan, New York.

Langston W. 1990. Toxic effects of metals and incidence of marine ecosystems. In: Furness RW, Rainbow PS (eds.) Heavy Metals in the Marine Environment. CRC Press, New York.

Liu P, Wang C, Song X, Wu Y. 2010. Dietary intake of lead and Cadmium by children and adults- result calculated from dietary recall and available lead/cadmium level in food in comparison to result from food duplicate diet method. Int J Hyg Environ Health 213: 450-457. DOI: $10.1016 /$ j.ijheh.2010.07.002 
Liu E, Wang X, Liu H, Liang M, Zhu, Y, Li Z. 2019. Chemical speciation, pollution and ecological risk of toxic metals in readily washed o road dust in a megacity (Nanjing), China. Ecotoxicol Environ Saf 173: 381-392.

Lone MI, He ZL, Stoffella PJ, Yang XE. 2008. Phytoremediation of heavy metal polluted soils and water: Progress and perspectives. J Zhejiang Univ Sci B 9: 210-220. DOI: 10.1631/jzus.B0710633

MAFF (Ministry of Agriculture, Fisheries and Food). 2000. Monitoring and surveillance of non-radioactive contaminants in the aquatic environment and activities regulating the disposal of wastes at sea, 1997. In: Aquatic Environment Monitoring Report No. 52. Center for Environment, Fisheries and Aquaculture Science, Lowestoft, UK.

Men C, Liu R, Wang Q, Guo L, Miao Y, Shen Z. 2019. Uncertainty analysis in source apportionment of heavy metals in road dust based on positive matrix factorization model and geographic information system. Sci Total Environ 652: 27-39.

Messner B, Knoflach M, Seubert A, Ritsch A, Pfaller K, Henderson B, Bernhard D. 2009. Cadmium is a novel and independent risk factor for early atherosclerosis mechanisms and in vivo relevance. Arterioscler Thromb Vasc Biol 29: 1392-1398. DOI: 10.1161/ATVBAHA.109.190082

Mitra A, Barua P, Zaman S, Banerjee K. 2012. Analysis of trace metals in commercially important crustaceans collected from UNESCO protected world heritage site of Indian Sundarbans. Turkish J Fish Aquat Sci 12: 53-66. DOI: 10.4194/1303-2712-v12_1_07

Mohmad J, Eqani S, Fasola M, Alamdar A, Mustafa I, Ali N, Liangpo L, Peng S, Shen H. 2015. Human exposure to toxic metals via contaminated dust: Bio-accumulation trends and their potential risk estimation. Chemosphere 132: 142-151.

Mujeeb A, Aziza I, Ahmed MZ, Sofia KA, Shafiq S. 2020. Comparative assessment of heavy metal accumulation and bio-indication in coastal dune halophytes. Ecotoxicol Environ Saf 195: 110486. DOI: 10.1016/j.ecoenv.2020.110486

Mukhtar I, Hannan A. 2012. Constrains on mangrove forests and conservation projects in Pakistan. J Coast Conserv 16: 51-62. DOI: 10.1007/s11852-011-0168-x

Muradoglu F, Gundogdu M, Ercisli S, Encu T, Balta F, Jaafar HZE, ZiaUl-Haq M. 2015. Cadmium toxicity affects chlorophyll a and b content, antioxidant enzyme activities and mineral nutrient accumulation in strawberry. Biol Res 48: 1-7. DOI: $10.1186 / \mathrm{S} 40659$ 015-0001-3

Narsimha A, Wang H. 2018. Distribution, contamination, and health risk assessment of heavy metals in surface soils from northern Telangana, India. Arab J Geosci 11 (21): 684. DOI: 10.1007/s12517-018-4028-y

Oikari A, Nakari T. 1982. Kraft pulp mill effluent components cause liver dysfunction in trout. Bull Environ Contam Toxicol 28 (3): 266-270. DOI: $10.1007 / \mathrm{BF} 01608505$

Oikari A, Soivio A. 1976. Physiological Condition of Fish Exposed to Water Containing Pulp and Paper Industry Wastes and Sewage. FAO, Rome, Italy.

Ogunlade MO, Agbeniyi SO. 2011. Impact of pesticides use on heavy metals pollution in cocoa soils of Cross-River State, Nigeria. Afr J Agri Res 6: 3725-3728.

Pal J, Shukla BN, Maurya AK, Verma HO, Pandey G, Amitha A. 2018. A review on role of fish in human nutrition with special emphasis to essential fatty acid. Int J Fish Aquat Stud 6 (2): 427-430.

Palaniappan PR, Karthikeyan S. 2009. Bioaccumulation and depuration of chromium in the selected organs and whole body tissues of freshwate fish cirrhinus mrigala individually and in binary solutions with nickel J Environ Sci 21 (2): 229-236. DOI: 10.1016/S1001-0742(08)62256-1

Perl DP, Olanow CW. 2007. The neuropathology of manganese-induced parkinsonism. J Neuropathol Exp Neurol 66: 675-682. DOI: 10.1097/nen.0b013e31812503cf

Rahman M, Islam M. 2010. Adsorption of Cd (II) ions from synthetic waste water using maple sawdust adsorption of $\mathrm{Cd}$ (II) ions from synthetic waste water using maple sawdust. Energy Sour Part A 32: 222-231. DOI: $10.1080 / 15567030802459297$

Rahman MS, Molla AH, Saha N, Rahman A. 2012. Study on heavy metals levels and its risk assessment in some edible fishes from Bangshi River, Savar, Dhaka, Bangladesh. Food Chem 134 (4): 1847-1854. DOI: 10.1016/j.foodchem.2012.03.099

Raja P, Veerasingam S, Suresh G, Marichamy G, Venkatachalapathy R. 2009. Heavy metals concentration in four commercially valuable marine edible fish species from Parangipettai Coast, South East Coast of India. Int J Anim Vet Adv 1 (1): 10-14.
Rajeshkumar S, Li X. 2018. Bioaccumulation of heavy metals in fish species from the Meiliang Bay, Taihu Lake, China. Toxicol Rep 5: 288-295. DOI: 10.1016/j.toxrep.2018.01.007

Rashed M. 2001. Monitoring of environmental heavy metals in fish from Nasser Lake. Environ Int 27 (1): 27-33. DOI: 10.1016/S01604120(01)00050-2

Roussel A, Andriollo-sanchez M, Ferry M, Bryden NA, Anderson RA. 2007. Food chromium content, dietary chromium intake and related biological variables in french free-living elderly. British J Nutr 98: 326-331. DOI: $10.1017 /$ S000711450770168X

Sadiq R, Husain T, Bose N, Veitch B. 2003. Distribution of heavy metals in sediment pore water due to offshore discharges: An ecological risk assessment. Environ Model Softw 18: 451-461. DOI: 10.1016/S13648152(03)00010-0

Saeedi M, Li LY, Salmanzadeh M. 2012. Heavy metals and polycyclic aromatic hydrocarbons: Pollution and ecological risk assessment in street dust of Tehran. J Hazard Mater 227: 9-17.

Saha N, Zaman MR. 2013. Evaluation of possible health risks of heavy metals by consumption of foodstuffs available in the central market of Rajshahi City, Bangladesh. Environ Monit Assess 185: 3867-3878. DOI: 10.1007/s10661-012-2835-2

Saher NU, Siddiqui AS. 2017. Evaluation of heavy metals contamination in mangrove sediments and their allied fiddler crab species (Austruca sindensis (Alcock, 1900) from Hawks Bay, Karachi, Pakistan. Int J Biol Biotech 14 (3): 411-417.

Saher NU, Kanwal N. 2018. Some biomonitoring studies of heavy metals in commercial species of crustacean along Karachi coast, Pakistan. Int J Biol Biotech 15 (2): 269-275.

Salnikow K, Kasprzak KS. 2005. Ascorbate depletion: A critical step in nickel carcinogenesis? Environ Health Perspect 113 (5): 577-584. DOI: $10.1289 /$ ehp. 7605

Sarkar B. 1999. Treatment of Wilson and Menkes diseases. Chem Rev 99: 2535-2544.

Sary AA, Mohammadi M. 2011. Human health risk assessment of heavy metals in fish from freshwater. Res J Fish Hydrobiol 6 (4): 404-411.

Scherz H, Kirchhoff E. 2006. Trace elements in foods: Zinc contents of raw foods-a comparison of data originating from different geographical regions of the world. J Food Compos Anal 19: 420-433. DOI: 10.1016/j.jfca.2005.10.004

Schnaas L, Rothenberg SJ, Flores M, Martinez S, Hernandez C, Osorio E, Perroni E. 2006. Reduced intellectual development in children with prenatal lead exposure. Environ Health Perspect 114 (5): 791-797. DOI: $10.1289 /$ ehp. 8552

Sfakianakis DG, Renieri E, Kentouri M, Tsatsakis AM. 2015. Effect of heavy metals on fish larvae deformities: A review. Environ Res 137: 246-255. DOI: 10.1016/j.envres.2014.12.014

Shafiq M, Iqbal MZ, Arayne M, Athar M. 2012. Biomonitoring of heavy metal contamination in Pongamia Pinnata and Peltophorum Pterocarpum growing in the polluted environment of Karachi. J Appl Bot Food Qual 85: 120-125.

Shahab A, Qi S, Rashid A, Hasan F, Sohail MT. 2016. Evaluation of water quality for drinking and agricultural suitability in the lower Indus plain in Pakistan. Pol J Environ Stud 25: 2563-2574.

Shaheen A, Baig HS, Kazmi SU. 2016. Microbial flora isolated from polluted and non-polluted coastal waters of Karachi. Pak J Bot 48: 1703-1708.

Shahid I, Kistler M, Mukhtar A, Ghauri BM, Ramirez-Santa Cruz C, Bauer H, Puxbaum H. 2016. Chemical characterization and mass closure of PM10 and PM2.5 at an urban site in Karachi-Pakistan. Atmos Environ 128: 114-123.

Siddiqui AS, Saher NU. 2015. Heavy metals distribution in sediments and their transfer rate to benthic fauna in mangrove area near hawks bay karachi, Pakistan. Pak J Mar Sci 24 (1\&2): 9-17.

Sivaperumal P, Sankar TV, Nair PGV. 2007. Food chemistry heavy metal concentrations in fish, shellfish and fish products from internal markets of India vis-a-vis international standards. Food Chem 102: 612-620. DOI: $10.1016 /$ j.foodchem.2006.05.041

Song Y, Elias V, Loban A, Scrimgeour AG, Ho E. 2010. Marginal zinc deficiency increases oxidative DNA damage in the prostate after chronic exercise. Free Radic Biol Med 48: 82-88. DOI: 10.1016/j.freeradbiomed.2009.10.030

Stern BR, Solioz M, Krewski D, Aggett P, Aw T-C, Baker S, Starr T. 2007. Copper and human health: Biochemistry, genetics, and strategies for modeling dose-response relationships. J Toxicol Environ Health 10: 157-222. DOI: 10.1080/10937400600755911 
Stipanuk MH, Caudill MA. 2012. Biochemical, Physiological, and Molecular Aspects of Human Nutrition. 3rd Edition. Elsevier Saunders Publishing, Philadelphia.

Sulieman HMA, Suliman EM. 2019. Appraisal of heavy metal levels in some marine organisms gathered from the Vellar and Uppanar estuaries Southeast Coast of Indian Ocean. J Taibah Univ Sci 13 (1) 338-343. DOI: 10.1080/16583655.2019.1576276

Sun WH, Jiang YX, Li X. 2013. Research of the evaluation on heavy metal pollution in rice by sewage irrigation. Appl Mech Mater 295 298: 1594-1599.2 DOI: 10.4028/www.scientific.net/AMM.295298.1594

Thomas LDK, Hodgson S, Nieuwenhuijsen M, Jarup L. 2009. Early kidney damage in a population exposed to cadmium and other heavy metals. Environ Health Perspec 117 (2): 181-184. DOI: 10.1289/ehp. 11641

Tian S, Liang T, Kexin L. 2019. Fine road dust contamination in a mining area presents a likely air pollution hotspot and threat to human health Environ Int 128: 201-209.

Tulasi G, Rao KJ. 2014. Essentiality of chromium for human health and dietary nutrition. J Entomol Zool Stud 2 (1): 107-108.

Tüzen M. 2003. Determination of heavy metals in fish samples of the middle Black Sea (Turkey) by graphite furnace atomic absorption spectrometry. Food Chem 80 (1): 119-123. DOI: 10.1016/S03088146(02)00264-9

U.S. Department of Health and Human Services. 2004. Toxicological Profile for Copper (Public Hea., pp. 1-314). Agency for Toxic Substances and Disease Registry.

Ullah AKMA, Maksud MA, Khan SR, Lutfa LN, Quraishi SB. 2017. Dietary intake of heavy metals from eight highly consumed species of cultured fish and possible human health risk implications in Bangladesh. Toxicol Rep 4: 574-579.

Umar A, Umar R, Ahmad MS. 2001. Hydrogeological and hydrochemica frame works of regional aquter system in Kali-Ganga Sub-Basin. India Envir Geol 40 (4-5): 602-611. DOI: 10.1007/s002540000215

Uriu-adams JY, Keen CL. 2010. Zinc and reproduction: Effects of zinc deficiency on prenatal and early postnatal development. Birth Defects Res (Part B) 89: 313-325. DOI: 10.1002/bdrb.20264

Uysal K, Emre Y, Köse E. 2008. The determination of heavy metal accumulation ratios in muscle, skin and gills of some migratory fish species by Inductively Coupled Plasma-Optical Emission Spectrometry (ICP-OES) in Beymelek Lagoon (Antalya/Turkey). Microchem J 90 (1): 67-70. DOI: 10.1016/j.microc.2008.03.005

Van Hassel JH, Ney JJ, Garling DL. 1980. Heavy metals in a stream ecosystem at sites near highways. Trans Am Fish Soc 109: 636-643.

Vettori MV, Alinovi R, Belletti S, Goldoni M, Franchini I, Multi A. 2003. In vitro model for the evaluation of the neurotoxicity of methyl mercury. Curr State Knowl Med Lav 94 (2): 183-191.

World Health Organization (WHO). 1989. Heavy Metals Environmental Aspects. Environmental Health Criteria. No. 85, Geneva.

Xue Z, Liu S, Liu Y, Yan YL. 2012. Health risk assessment of heavy metals for edible parts of vegetables grown in sewage-irrigated soils in suburbs of Baoding City, China. Environ Monit Assess 184 (6): 3503-3513. DOI: 10.1007/s10661-011-2204-6

Yasmeen K, Mirza AM, Khan NA, Kausar N, Attaur R, Hanif M. 2016. Trace metals health risk appraisal in fish species of Arabian Sea. SpringerPlus 5: 859. DOI: 10.1186/s40064-016-2436-6

Yi YJ, Zhang S.H. 2012. The relationships between fish heavy metal concentrations and fish size in the upper and middle reach of Yangtze River. The $18^{\text {th }}$ Biennial Conference of International Society for Ecological Modelling. Proc Environ Sci 13: 1699-1707.

You SH, Wang SL, Pan WH, Chan WC, Fan AM, Lin P. 2018. Risk assessment of methylmercury based on internal exposure and fish and seafood consumption estimates in Taiwanese children. Int $\mathbf{J}$ Hyg Environ Health 221: 697-703.

Yousif RA, Masyamsir, Dhahiyat, Sunarto, Zahidah. 2016. Assessment the levels of heavy metals and water quality in Cikuda River, Indonesia. Glob J Bio-Sci Biotechnol 5 (2): 240-244.

Yousuf F, Ahmed Q. 2010. Heavy metals ( $\mathrm{Cu}, \mathrm{Fe}, \mathrm{Mn}, \mathrm{Zn})$ content in Thunnus tonggol (Family-Scombridae) from Karachi coast. Karachi Univ J Sci 38: 5-9.

Yousuf F, Ahmed Q. 2011. Concentration of heavy metals in liver and muscles of fish, Rastrelliger kanagurta, from the coast of Karachi, Pakistan. Int J Biol Biotechnol 8: 543-550.

Zheng G, Tian L, Liang Y, Broberg K, Lei L, Guo W, Nilsson J, Bergdahl IA, Skerfving S, Jin T. 2011. $\delta$-Aminolevulinic acid Dehydratase genotype predicts toxic effects of lead on workers' peripheral nervous system. Neurotoxicol 32: 374-382. DOI: 10.1016/j.neuro.2011.03.006 